\title{
Awareness of the causes, impact and solutions to global warming among undergraduate students from different schools in the University of The Gambia
}

\author{
Matty kah ${ }^{1}$ \\ Alpha Kargbo ${ }^{2 *}$ \\ Pierre A. Mendy ${ }^{2}$ \\ Edrisa Jawo ${ }^{3}$ \\ Edward Mendy ${ }^{4}$
}

\begin{abstract}
Climate Change is unequivocal and occurring at an alarming pace. Increasing greenhouse gas emissions, their concentration in the atmosphere and increased energy absorption have resulted in in changes in climate. This study was a cross sectional study conducted from April 12th to May 12th, 2021. The survey was conducted online using Google form that was circulated via "WhatsApp" groups and emails received from the University admissions office. This study comprises of students in their; first year 26.5\%, second year $22.8 \%$, third year $17.9 \%$ and fourth-year students 32.8\%. Students from the school of Medicine and allied health science showed a satisfactory knowledge of $67 \%$ towards the causes of global warming. Students from the school of Engineering also demonstrated a satisfactory knowledge towards the impact of global warming $61 \%$ and its solution $69 \%$. In conclusion, students at the University of The Gambia demonstrated a satisfactory understanding of the causes of global warming (63\%) and a fair awareness of the consequences (52\%) and remedies to global warming (54\%). We recommend that, climate change awareness course should be incorporated into the curriculum of the University of The Gambia and should be made mandatory for every student.
\end{abstract}

Keywords: Global warming, awareness, undergraduate, university of The Gambia

${ }^{1}$ School of Agriculture and Environmental Sciences, the University of The Gambia

${ }^{2}$ School of Arts and Sciences, the University of The Gambia

${ }^{3}$ Research Directorate, the University of The Gambia

${ }^{4}$ Tsunami and Disaster Mitigation Research Center- Universitas Syiah Kuala,Indonesia- Banda Aceh

*Corresponding author: akargbo@utg.edu.gm

Received on September $13^{\text {th }}, 2021 /$ Accepted on November $24^{\text {th }}, 202 /$ Published online on December 19, 2021

Ghana Journal of Geography Vol. 13 (3), 2021 pages 258-277

Doi: https://dx.doi.org/10.4314/gjg.v13i3.12 


\section{Introduction}

It is obvious that although parallel research has established that the scientific world has come to a near-unanimous agreement that climate change is human-induced there are still individuals with different opinions on the issue particularly in the United States (Van der Linden et al., 2017). Intermittently, the International Panel on Climate Change (IPCC) releases a summary of the state of scientific research about climate change. Such research has shown that recent global warming has elevated anthropogenically in the Second Assessment Report Cook (2019). One of the primary causes of climate change is global warming. Although global warming is a natural phenomenon, anthropogenic active ties in the environment can worsen it. In the first decades of the twenty-first century, there will be a gradual warming of 1-2 degrees Celsius (Dewi \& Khoirunisa, 2018). Global Climate Change is unequivocal and occurring at an alarming pace, according to evidences available (IPCC 2013; Huang et al., 2017). Arid and semi-arid rangelands, which occupy nearly two-thirds of the African continent, are predicted to be heavily impacted by climate change (IPCC 2013). The most significant contributors to climate change are greenhouse gases. Water vapor $\left(\mathrm{H}_{2} \mathrm{O}\right)$, carbon dioxide $\left(\mathrm{CO}_{2}\right)$, methane $\left(\mathrm{CH}_{4}\right)$, nitrous oxide $\left(\mathrm{N}_{2} \mathrm{O}\right)$, and fluorinated gases such as hydrofluorocarbons (HFCs), perfluorocarbons (PFCs), and sulfur hexafluoride (SF6) are all greenhouse gases (GHGs). Climate warming is one of the most serious and pressing issues facing the planet (Ozbayrak et al., 2011; Freijeet al., 2017). Increasing greenhouse gas emissions, their concentration in the atmosphere, and increased energy absorption have resulted in rising temperatures and climate change (Dutta \& Radner, 2009). Climate change has devastating impacts on humans and the natural systems. Impacts on living standards, health and well-being, habitats and species, utilities, facilities, and economic, social, and cultural assets can have positive or negative consequences (Global climate action, 
2019). Despite the fact that the COVID-19 crisis has dominated both the news and policymaking, causing significant hardship and economic and social disruption, the UNEP 2020 Emissions Gap Report shows that the COVID-19 crisis has caused immense suffering and economic and social disruptions. The economic downturn has temporarily slowed but not stopped the historic and ever-increasing impact of human activity on the planet. The planet is already on track to warm by more than $3^{\circ} \mathrm{C}$ this century, far exceeding the Paris Agreement's targets of reducing global warming far below $2^{\circ} \mathrm{C}$ and aiming for $1.5^{\circ} \mathrm{C}$ (IPCC 2018; UNEP 2020). Whereas the recent announcements of net-zero emission targets are promising, they illustrate the significant gap between the ambition of these goals and the lack of ambition in the 2030 NDCs. In addition, there is a discrepancy between the emission levels implied by current policies and those expected under current NDCs by 2030, and, more specifically, those needed to achieve net-zero emissions by 2050. (UNEP 2020). Climate change and variability are two of the most common silent crises affecting agricultural production in recent decades, and their effects are not readily apparent or easy to avoid. Sadly, Africa is widely recognized as the most vulnerable continent to the effects of climate change, with West Africa being a particular source of concern due to its limited ability to adapt to climate extremes (Badjie et al., 2019). According to Badjie et al., (2019), The Gambia is one of the most vulnerable countries that is affected by rising sea levels. By 2075, average the temperatures are predicted to rise by 3 to 4.5 degrees Celsius. Although The Gambia's greenhouse gas (GHG) emissions are low, there are pieces of evidence of climate variability. The Gambia, on the other hand, is a party to the treaty to the UN Framework Convention on Climate Change (UNFCC) and is working towards the reduction of GHG emissions. The Gambia has established and is implementing National Adaptation Programmes of Action (NAPAs) to counter the challenges of climate change (Badjie et al., 2019). Students' awareness of the climate, global 
warming, and greenhouse effects in tertiary institutions is expected to be among the highest among students in the formal educational pyramid, and a significant indicator of general population knowledge (AbuQamar et al., 2015; Freije et al., 2017). To the best of our knowledge, there is little or no research on students' knowledge of environmental problems in general and global warming, in particular, among undergraduate students in The University of The Gambia. The aim of this study was to establish the knowledge of students in The University of The Gambia knew about global warming and the greenhouse effect. This would aid in identifying gaps in students' perceptions in order to suggest changes to all stakeholders in higher education.

\section{Methods}

\section{Study design}

This research was a cross sectional study conducted from April 12th to May 12th, 2021. The survey was conducted online using Google Forms that were circulated via "WhatsApp" groups and emails received from the university admissions office as well as individual lecturers at each of the university's schools. This was because of the online system of learning which The University of The Gambia adopted due to Covid-19 pandemic in the country. The majority of students at the university only took online courses. Students over the age of 18 who agreed to participate in the study were informed of the aim and objectives of the study were asked to complete the questionnaire by clicking on the link. To affirm their readiness to participate willingly, participants had to answer a yes or no question. Following the confirmation, the participants were instructed to complete the self-completed questionnaire. The estimation of the sample size was done by assuming a minimum prevalence of $50 \%$, confidence level $=95 \%$, and 
$\mathrm{d}$ (margin of error) $=0.05$. The calculated minimum sample size of this study was 384 participants but 451 participants volunteered to participate in this survey.

\section{Questionnaires and Data Processing}

The questionnaire (Freije et al., 2017) was used, and it was divided into two sections. The first section of the questionnaire was on the participants' demographics, while the second section included questions for the perception evaluation. Age, gender, and religion were among the demographic variables. The questionnaire had seven (7) questions about the cause, 11 questions about the impact, and 4 questions about the solutions.

\section{Statistical analysis}

The frequencies of correct knowledge responses and various attitudes and practices were described using Microsoft words. Data were further analyzed using IBM SPSS 25.0 software (SPSS Inc., Chicago, IL, USA). Percentage and frequency were examined employing descriptive statistics. Pearson's chi-square was used to compare variables. The level of statistical significance was established at $p<0.05$. The student's perception was scored when average correct answers for cause, impact and solution to global warming were $>40 \%=$ poor perception, $41 \%$ to $55 \%$ average, $56 \%$ to $75 \%=$ good knowledge and $76 \%$ to $100 \%$ very good perception.

\section{Results}

\section{Socio-demographic Characteristics of Study Participants}

Forty six percent $(46 \%)$ of the respondents in the study were between the ages of 21 and 25 , and $68 \%$ were men. Students from the School of Arts and Sciences made up the bulk of the 
respondents in this survey $(33 \%)$ and a total of $37 \%$ of the students were in their first year of their university education. (See Table 1).

Table 1: Socio-demographic characteristics of respondents.

\begin{tabular}{llll}
\hline Variables & Categories & Frequency & Percentage \\
\hline Gender & Male & 306 & 68 \\
Age & Female & 146 & 32 \\
& $16-20$ & 53 & 11.7 \\
& $21-25$ & 208 & 46 \\
& $26-30$ & 116 & 25.7 \\
\multirow{5}{*}{ School } & $31-35$ & 50 & 11.1 \\
& $>35$ & 25 & 5.5 \\
& Agriculture and Environment (A\&E) & 44 & 9.7 \\
& Arts and science (A\&S) & 147 & 32.5 \\
& Business and Public Administration (BPA) & 124 & 27.4 \\
& Education (Edu) & 46 & 10.2 \\
& Engineering (Eng) & & 2.7 \\
& Information Communication Technology (ICT) & 16 & 3.5 \\
& Law & 20 & 4.4 \\
& Medicine and Allied Health science (MAH) & 43 & 9.3 \\
& 100 & 120 & 26.5 \\
& 200 & 103 & 22.8 \\
& 300 & 81 & 17.9 \\
& 400 & 148 & 32.8 \\
\hline
\end{tabular}

\section{Students Perception of the Causes of Global warming by Respondents}

Less than half of the participants 223(49.3\%) agreed that, Solar energy speeds up global warming. Additionally, more than one third 403 (89.2) of the participants also agreed that, global warming has worsened due to the increase in Carbon dioxide gas emission. A good number of the students 75 (16.6\%) also believe that, nitrous oxide is the gas which has the greatest impact on the greenhouse effect (see Table 2). 
Table 2: Perceived cause of global warming by respondents $(n=452)$

\begin{tabular}{|c|c|c|}
\hline Indicative variables & Category & $\begin{array}{l}\text { Frequency } \\
(\%)\end{array}$ \\
\hline \multirow[t]{2}{*}{ Solar energy speeds up global warming } & True & $223(49.3)$ \\
\hline & False & $229(50.7)$ \\
\hline \multirow{2}{*}{$\begin{array}{l}\text { Global warming has worsened due to the increase in } \\
\text { Carbon dioxide gas }\end{array}$} & True & $403(89.2)$ \\
\hline & False & $49(10.8)$ \\
\hline \multirow{2}{*}{$\begin{array}{l}\text { Carbon dioxide levels in the atmosphere are increasing } \\
\text { as a result of fossil fuel combustion }\end{array}$} & True & $410(90.7)$ \\
\hline & False & $42(9.3)$ \\
\hline \multirow{2}{*}{$\begin{array}{l}\text { Greenhouse gases prohibit infrared rays escaping into } \\
\text { space }\end{array}$} & True & $374(82.7)$ \\
\hline & False & $78(17.3)$ \\
\hline \multirow{4}{*}{$\begin{array}{l}\text { Currently, the main environmental concern triggering } \\
\text { global warming is }\end{array}$} & Air pollution & $269(59.5)$ \\
\hline & Acid rain & $4(0.9)$ \\
\hline & Radioactive waste & $53(11.7)$ \\
\hline & Water, soil and land pollution & $126(27.9)$ \\
\hline \multirow[t]{4}{*}{ Greenhouse gases } & $\begin{array}{l}\text { Absorb ultraviolet radiation increases the } \\
\text { atmospheric heat }\end{array}$ & $223(49.3)$ \\
\hline & $\begin{array}{l}\text { Reflect infrared radiation increases the } \\
\text { atmospheric heat }\end{array}$ & $65(14.4)$ \\
\hline & $\begin{array}{l}\text { Reflect ultraviolet radiation thereby warming } \\
\text { the earth's surface and increasing the } \\
\text { atmospheric heat }\end{array}$ & $94(20.8)$ \\
\hline & $\begin{array}{l}\text { Absorb infrared radiation thereby warming } \\
\text { the earth's surface and increasing the } \\
\text { atmospheric heat. }\end{array}$ & $70(15.5)$ \\
\hline \multirow{4}{*}{$\begin{array}{l}\text { Which gas has the greatest impact on the greenhouse } \\
\text { effect? }\end{array}$} & Carbon dioxide & $319(70.6)$ \\
\hline & Helium & $19(4.2)$ \\
\hline & Nitrous Oxide & $75(16.6)$ \\
\hline & Ozone & $39(8.6)$ \\
\hline
\end{tabular}

\section{Students perception of the impact of global warming}

This study also shows that, $435(96.2 \%)$ of the respondents agreed that the average global sea level has risen during the past few years. Majority of the respondents $422(93.4 \%)$ also agreed that, global temperatures increase with the passage of time. Less than half of the respondents 160(35.4\%) are aware that, 50\% The Gambia's forest cover has been lost since 1940. Majority of the 
participants $327(72.3 \%$ ) agreed that, the world would be face with drought and desertification if global warming continues (Table 3).

Table 3: Perceived Impact of global warming by respondents $(n=452)$

\begin{tabular}{|c|c|c|}
\hline Indicative variables & Category & Frequency $\%$ \\
\hline \multirow{2}{*}{$\begin{array}{l}\text { The average global sea level has risen during the past few } \\
\text { years }\end{array}$} & True & $435(96.2)$ \\
\hline & False & $17(3.8)$ \\
\hline \multirow{2}{*}{$\begin{array}{l}\text { During the decade, the ice cover of Earth's two polar regions } \\
\text { has increased }\end{array}$} & True & $228(50.4)$ \\
\hline & False* & $224(49.6)$ \\
\hline \multirow[t]{2}{*}{ Global temperature increases with the passage of time. } & True & $422(93.4)$ \\
\hline & False* & $30(6.6)$ \\
\hline \multirow{2}{*}{$\begin{array}{l}\text { Degradation of the ozone layer has resulted in an increase in } \\
\text { the incidence of skin cancer in recent years }\end{array}$} & True* & $395(87.4)$ \\
\hline & False & $57(12.6)$ \\
\hline \multirow{2}{*}{$\begin{array}{l}\text { The ozone layer prevents the sun's ultraviolet rays from } \\
\text { penetrating the earth's atmosphere }\end{array}$} & True* & $416(92)$ \\
\hline & False & $36(8)$ \\
\hline \multirow{5}{*}{$\begin{array}{l}\text { What is the percentage of forest cover lost in the Gambia } \\
\text { since } 1940\end{array}$} & $20 \%$ & $61(13.5)$ \\
\hline & $20 \%$ & $61(13.5)$ \\
\hline & $30 \%$ & $84(18.6)$ \\
\hline & $40 \%$ & $147(32.5)$ \\
\hline & $50 \% *$ & $160(35.4)$ \\
\hline \multirow[t]{4}{*}{ What percentage of the Gambia is seasonally flooded } & $5 \%$ to $10 \%$ & $133(29.4)$ \\
\hline & $10 \%$ to $20 \% *$ & $190(42)$ \\
\hline & $25 \%$ to $30 \%$ & $92(20.4)$ \\
\hline & $10 \%$ to $40 \%$ & $37(8.2)$ \\
\hline \multirow{4}{*}{$\begin{array}{l}\text { Which of the following years has been the hottest year on } \\
\text { record }\end{array}$} & 2016 & $100(22.1)$ \\
\hline & 2020 & $113(25)$ \\
\hline & Both 2016 \& 2020* & $158(35)$ \\
\hline & None of the above & 81(17.9) \\
\hline \multirow[t]{4}{*}{ The most ideal definition of global warming is } & The emission of gases in the atmosphere & $283(62.6)$ \\
\hline & The excessive emission of gases & $35(7.7)$ \\
\hline & The rise of temperature on earth* & $108(23.9)$ \\
\hline & $\begin{array}{l}\text { The study of human impact on the } \\
\text { environment }\end{array}$ & $26(5.8)$ \\
\hline \multirow[t]{4}{*}{ The following will occur as a result of climate change except } & Windstorms & $130(28.8)$ \\
\hline & Killer floods and forest fires & $72(15.9)$ \\
\hline & excessive heat waves & $90(19.9)$ \\
\hline & Abnormal diseases* & $160(35.4)$ \\
\hline \multirow{4}{*}{$\begin{array}{l}\text { What do you think we will have to deal with if global } \\
\text { warming continues? }\end{array}$} & Water desalination & $44(9.7)$ \\
\hline & Increased ice fields & $40(8.8)$ \\
\hline & Sea level decline & $41(9.1)$ \\
\hline & Drought and desertification* & $327(72.3)$ \\
\hline
\end{tabular}




\section{Students perception of the solution to global warming}

A good number of the respondents 156 (34.5) do not believe that, taking public transportation instead of driving a private car will help in reducing global warming. Seventy eight percent of the students also believe that, increase in water consumption and use of non-recyclable product is a way we can personally help to mitigate global warming at home or at personal level (Table 4).

Table 4: Perceived solution of global warming by respondents

\begin{tabular}{|c|c|c|}
\hline Indicative variables & Category & Frequency $\%$ \\
\hline \multirow{2}{*}{$\begin{array}{l}\text { In general, taking public transportation instead of driving } \\
\text { a private car will help in reducing global warming }\end{array}$} & True* & $296(65.5)$ \\
\hline & False & $156(34.5)$ \\
\hline \multirow[t]{2}{*}{ Wasting less food is a way to reduce greenhouse gas } & True* & $300(66.4)$ \\
\hline & False & $152(33.6)$ \\
\hline \multirow[t]{4}{*}{ The largest grassland area in The Gambia is found in } & West Coast Region & $125(27.7)$ \\
\hline & North Bank Region & $82(18.1)$ \\
\hline & Central River Region* & $153(33.8)$ \\
\hline & Upper River Region & $92(20.4)$ \\
\hline \multirow{4}{*}{$\begin{array}{l}\text { What do you think you can do at home or at personal } \\
\text { levels to help mitigate global warming? }\end{array}$} & Increase water consumption & $78(17.3)$ \\
\hline & Reduce electricity consumption* & $214(47.3)$ \\
\hline & Increase waste products (garbage) & $36(8)$ \\
\hline & Use non-recyclable products & $78(17.3)$ \\
\hline
\end{tabular}

Chi-square test result of positive knowledge regarding the causes, impact and solution towards global warming among students at the University of The Gambia

The chi-square test results showed in table 5 indicates that, there was no statistically significant difference between respondents from the various schools at the University of The Gambia and their knowledge about the causes of global warming. However, students from the School of Medicine and Allied Health Science had the highest knowledge scores about the causes of global warming in this study (67\%) whiles students from both school of Business and Public Administration and Information, Communication and Technology had the lowest scores (61\%) 
each. This result also shows that, student's general knowledge about the causes of global warming was graded as good (63\%). 
Table 5: Chi-square test result of positive knowledge regarding the cause of global warming among students in the various schools at the University of The Gambia

\begin{tabular}{|c|c|c|c|c|c|c|c|c|c|c|}
\hline $\begin{array}{l}\text { Perceived cause of global } \\
\text { warming }\end{array}$ & $\begin{array}{l}A \& E \\
(N=44)\end{array}$ & $\begin{array}{l}A \& S \\
(N=147)\end{array}$ & $\begin{array}{l}\text { BPA } \\
(\mathrm{N}=124)\end{array}$ & $\begin{array}{l}\text { Edu } \\
(\mathrm{N}=46)\end{array}$ & $\begin{array}{l}\text { Eng } \\
(\mathrm{N}=12)\end{array}$ & $\begin{array}{l}\text { ICT } \\
(\mathrm{N}=16)\end{array}$ & $\begin{array}{l}\text { LAW } \\
(\mathrm{N}=20)\end{array}$ & $\begin{array}{l}\text { MAH } \\
(\mathrm{N}=43)\end{array}$ & $\mathrm{X}^{2}$ & $P$ value \\
\hline Solar energy & $21(48)$ & $65(44)$ & $72(58)$ & $22(48)$ & $4(33)$ & $8(50)$ & $9(45)$ & $22(51)$ & 7.78 & 0.445 \\
\hline Increase in Carbon dioxide gas & $40(91)$ & $132(90)$ & $112(90)$ & $41(89)$ & $12(100)$ & $12(75)$ & $15(75)$ & $39(91)$ & 0.302 & 0.302 \\
\hline Fossil fuel combustion & $40(91)$ & 134(91) & 111(90) & $41(89)$ & $11(92)$ & $16(100)$ & $17(85)$ & $39(91)$ & 3.181 & 0.922 \\
\hline $\begin{array}{l}\text { Infrared rays (heat) do not } \\
\text { escaping from space }\end{array}$ & $38(89)$ & $124(84)$ & $99(80)$ & $40(87)$ & $10(83)$ & $12(75)$ & $16(80)$ & $34(79)$ & 3.921 & 0.864 \\
\hline Greenhouse gases & $23(52)$ & 71(48) & $56(45)$ & $23(50)$ & $4(33)$ & $12(75)$ & $11(55)$ & $23(53)$ & 29.457 & 0.203 \\
\hline $\begin{array}{l}\text { The impact on the greenhouse } \\
\text { effect, accounting for nearly } 80 \% \\
\text { of it? }\end{array}$ & $36(82)$ & 103(70) & $79(64)$ & $28(61)$ & $11(92)$ & $14(88)$ & $15(75)$ & $33(77)$ & 32.683 & 0.111 \\
\hline $\begin{array}{l}\text { The primary gas responsible for } \\
\text { the ozone layer's "hole" is }\end{array}$ & $18(41)$ & $74(50)$ & $43(35)$ & $17(37)$ & $5(42)$ & $4(25)$ & $9(45)$ & $24(56)$ & 22.108 & 0.573 \\
\hline $\begin{array}{l}\text { The increased emissions of } \\
\text { greenhouse gases }\end{array}$ & $13(30)$ & $48(33)$ & $32(26)$ & $16(35)$ & $3(25)$ & $3(19)$ & $5(25)$ & $21(49)$ & 15.918 & 0.881 \\
\hline $\begin{array}{l}\text { Average percent of positive } \\
\text { responds }\end{array}$ & $63 \%$ & $64 \%$ & $61 \%$ & $62 \%$ & $63 \%$ & $61 \%$ & $63 \%$ & $67 \%$ & & \\
\hline Total percent & $63 \%$ & & & & & & & & & \\
\hline
\end{tabular}

*significant difference, ${ }^{\text {ns }}$ No significant difference

Table 6 shows that, there was a strong significant level between students' school of enrolment and their ability to understand some of the impact of global warming. Students from the school of Engineering had the highest knowledge scores (61\%) and those from 
Business and Public Administration had the lowest scores (49\%) about the impact or the consequences of global warming. This result also shows that, student's general knowledge about impact of global warming was rated as good (52\%).

Table 6: Chi-square test result of knowledge regarding the impact of global warming among students in the various schools at the University of The Gambia.

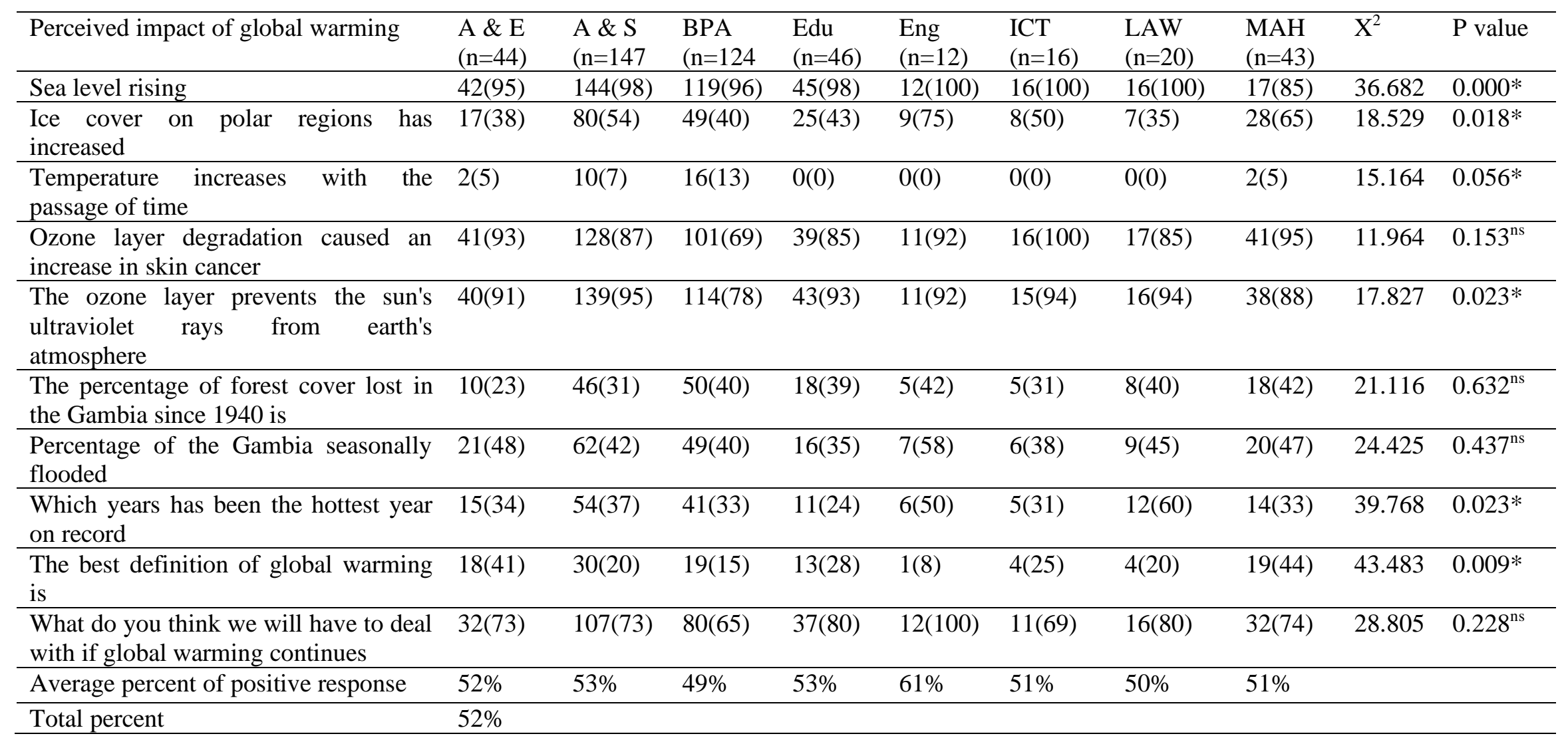

*Significant difference, ${ }^{\mathrm{ns}}$ no significant difference 
The chi-square test result in table 7 also shows that, there was a strong significant level between students' school of enrolment and their ability to understand some of the solutions to global warming. Students from the school of Engineering had the highest knowledge scores (69\%) and those from the school of Law had the lowest scores (36\%) about the solution towards global warming.

This result also shows that, student's general knowledge towards the solutions to global warming was rated as good (54\%).

Table 7: Chi-square test result of positive knowledge regarding the solution of global warming among students in the various schools at the University of The Gambia.

\begin{tabular}{|c|c|c|c|c|c|c|c|c|c|c|}
\hline $\begin{array}{l}\text { Perceived solution of global } \\
\text { warming }\end{array}$ & $\begin{array}{l}\text { A \& E } \\
(n=44)\end{array}$ & $\begin{array}{l}\text { A \& S } \\
(n=147)\end{array}$ & $\begin{array}{l}\mathrm{BPA} \\
(\mathrm{n}=124)\end{array}$ & $\begin{array}{l}\text { Edu } \\
(n=46)\end{array}$ & $\begin{array}{l}\text { Eng } \\
(n=12)\end{array}$ & $\begin{array}{l}\text { ICT } \\
(n=16)\end{array}$ & $\begin{array}{l}\mathrm{LAW} \\
(\mathrm{n}=20)\end{array}$ & $\begin{array}{l}\text { MAH } \\
(n=43)\end{array}$ & $\mathrm{X}^{2}$ & $\mathrm{P}$ value \\
\hline $\begin{array}{l}\text { Using a public transportation } \\
\text { is better than driving once } \\
\text { own car. }\end{array}$ & $36(81)$ & $98(67)$ & $74(60)$ & $33(72)$ & 11(92) & 11(69) & $7(35)$ & $26(60)$ & 20.498 & $0.009 *$ \\
\hline Wasting less food & $30(68)$ & $99(67)$ & $82(66)$ & $27(59)$ & $11(92)$ & $12(75)$ & $12(60)$ & $27(63)$ & 6.394 & $0.603^{\text {ns }}$ \\
\hline $\begin{array}{l}\text { The largest grassland area in } \\
\text { The Gambia is found in }\end{array}$ & $17(39)$ & $53(36)$ & $36(29)$ & $21(46)$ & $4(33)$ & $6(38)$ & $6(30)$ & $10(23)$ & 27.513 & $0.281^{\mathrm{ns}}$ \\
\hline $\begin{array}{l}\text { Mitigation to adopt at home } \\
\text { could be? }\end{array}$ & $26(59)$ & $84(57)$ & $39(31)$ & $25(54)$ & $7(58)$ & $9(56)$ & $4(20)$ & $20(47)$ & 47.128 & $0.003 *$ \\
\hline $\begin{array}{l}\text { Average percent of positive } \\
\text { response }\end{array}$ & $62 \%$ & $57 \%$ & $47 \%$ & $58 \%$ & $69 \%$ & $59 \%$ & $36 \%$ & $48 \%$ & & \\
\hline Total percent & $54 \%$ & & & & & & & & & \\
\hline
\end{tabular}

*significant difference ${ }^{\mathrm{ns}}$ no significant difference 


\section{Discussion}

Global warming is one of the most pressing global problems today. The negative effects of global warming may be devastating, posing a threat to the survival of humanity. As a result, it is critical for everyone, especially those in the University community to have a thorough understanding of the problem as well as possible solutions so that they can implement the required changes in economies, resource use, attitudes, and general attitude toward nature (Aydin, 2010; Freije et al., 2016). To the best of our knowledge, this is the first study in the region testing university students' perception about global warming. In this study, there were 440 respondents comprising of $67.8 \%$ of male and $32.2 \%$ female. The majority of students (46\%) were of between 21-25 years. Similar findings were seen in a study conducted on climate change by Haq and Ahmed (2020) in which, (63\%) were male and (37\%) were female. The perception of global warming was divided into some categories including causes, impacts and solutions.

When it comes to students' perceptions of global warming as a cause, we discovered in our study that $100 \%$ of the respondents have heard of global warming. This finding is also in line with the findings of (Dewi and Khoirunisa 2018; Kumar et al. 2019), who discovered that the majority of respondents were concerned about the environment and global warming. Surprisingly, 50.7\% of students are aware that solar energy does not contribute to global warming. Eighty nine percent of respondents attributed the aggravated state of global warming to the increased carbon dioxide gas in the atmosphere. The findings of this study are likewise similar to those of Freije et al. (2016). Furthermore, when asked which gas creates greenhouse effect and what the main source of this gas is, $70.6 \%$ and $90.7 \%$ of the students gave right answers respectively. According to the findings of this study, $70 \%$ of students had a favorable opinion on the causes of global warming. This investigation supports the findings of (Freije et al., 2016; Yang et al., 2018). The results of 
the chi-square test revealed no statistical significance between any of the questions asked about the cause of global warming among students from different schools. In general, $63 \%$ of the students had a favorable opinion of the cause of global warming. Students in the School of Medicine and Allied Health Sciences had the highest right answers $67 \%$ on the cause of global warming. This was then followed by School of Arts and Sciences 64\%, Agriculture and Environmental Sciences 63\%, Engineering 63\%, Law 63\%, Education $62 \%$ and finally students from the School of Business and Public Administration 61\% and ICT 61\% had the lowest (table 5). The amount of global warming awareness among UTG students particularly those in the School of Medicine and Allied Health Sciences who allegedly received the highest results in the West African Senior Secondary School Certificate Examinations (WASSCE), could be attributed to the knowledge they learned during their high school education. This finding is comparable to that of Parashar et al. (2013), who established that the majority of Meerut medical students showed a high level of understanding about global warming.

This study also revealed that $435(96.2 \%)$ of the students were aware that sea levels have been rising in recent years. $422(93.4 \%)$ of the students believe that global average temperatures have risen over time. The ozone layer prevents UV rays from penetrating the planet, according to 416 (92\%) of the students. Only few students $108(23.9 \%)$ were able to define the term global warming as the rise of temperature on earth and only $327(72.3 \%)$ of the students were aware that global warming can be a driver of more drought and desertification. Furthermore, 395 students $(87.4 \%)$ were aware of the negative consequences of ozone depletion. They claim that it raises the risk of skin cancer. Parashar et al. (2013) also discovers similar finding in their work. They found that $62.5 \%$ of respondents were aware of the functions of the ozone layer, and another 57.5\% were aware that ozone layer depletion resulted into more cases of skin cancer. 
According to (Index \& Mundi 2019; Foroyaa 2018; Amuzu et al., 2018). The Gambia has lost more than half of its forest cover, and the country is experiencing seasonal flooding of $10 \%$ to $20 \%$. Nonetheless, less than half of the students in this study were able to respond to questions about the challenges faced by The Gambia because of globalization. Only $160(35.4 \%)$ and 190 (42\%) of those polled correctly guessed the percentage of forest loss in The Gambia since 1940 and the proportion of The Gambia that is periodically flooded. In comparison, students from the School of Engineering had the highest percentage of correct answers (61\%) and students from the School of Business and Public Administration had the lowest percentage (49\%) of accurate answers. In general, overall students demonstrated an average perception of $52 \%$ when asked about their perception of the impact of global warming (Table 6).

When asked whether they would prefer to take public transport instead of driving their own automobiles, students responded positively. In all 296, constituting (65.5\%) of the respondents responded positively. Sixty-one percent of the students also believe that discarding less food will help in the reduction of greenhouse gas emissions. In addition, when asked what behaviors they would implement at home to help prevent global warming, $214(47.3 \%)$ of the students stated that they would cut electricity use, $78(17.3 \%)$ prefer to increase water supply, $36(8 \%)$ would increase waste products, and 124 (27.4\%) would use non-recyclable products. Finally, only 153 (33.8\%) of the students are aware that The Gambia's Central River Region contains the country's greatest grassland area. Other variables could not be compared since no research has been conducted there. As shown in Table 6 and 7, the cross-tabulation analysis with chi square result reveals statistical significance among UTG students and several questions. This result further suggests that students' involvement with an environmental organization, experience of high temperatures in their hometown and school are significant in explaining associations with their 
perceptions towards the impact and solution of global warming. Engineering students received the highest percentage of accurate answers (69\%) followed by Agriculture and Environmental Sciences students (62\%). In this survey, students from the Law School had the lowest impression of the answer to global warming (table 7). Overall, the students at UTG were rated as average with a score of $54 \%$.

\section{Conclusion}

In conclusion, it was established in this study that students of The University of The Gambia had enough understanding of the causes of global warming and average awareness of the consequences and remedies to global warming. The Government should among other things, guarantee a strategic intervention in building and enhancing publicity programs on environmental issues and public awareness on global warming is made at the University of The Gambia, which is the country's highest epicenter of higher education. Higher education curricula, as well as primary and secondary school curricula, should be examined in order to incorporate a global warming component into their current curriculum. We recommend that, Management of the University of The Gambia should come up with a variety of programs that will help to raise global warming awareness. To begin with, climate change and global warming should be made a general education requirement course or seminar for all UTG students. Secondly, The University of The Gambia management should support and encourage commemorations of events such as World Earth Day (April 22nd) and World Environmental Day (June 5th) by assembling students and making a presentation on the significance of the ceremonies on a yearly basis. 


\section{Acknowledgements}

We want to thank the entire management and administration of The University of The Gambia, for their approval and support during the course of this work. We also would like to thank the entire teaching staff and students of the 2020-2021 academic year of the University of The Gambia, especially those who helped to administer and participate in this study.

\section{References}

AbuQamar, S., Alshannag, Q., Sartawi, A., \& Iratni, R. (2015). Educational awareness of biotechnology issues among undergraduate students at the United Arab Emirates University. Biochem. Mol. Biol. Educ. 43 (4), 283-293.

Amuzu, J., Jallow, BP., Kabo-Bah, AT., \& Yaffa, S. (2018). The Climate Change Vulnerability and Risk Management Matrix for the Coastal Zone of The Gambia. Hydrology 2018, 5, 14; doi:10.3390/hydrology5010014.

Aydin, F. (2010). Secondary school students' perceptions towards global warming: a phenomenographic analysis. Sci. Res. Essays 5 (12), 1566-1570.

Badjie, M., Yaffa, S., Sawaneh, M., \& Bah, A. (2019). Effects of climate variability on household food availability among rural farmers in Central River Region-South of The Gambia. Climate Change, 5(17), 1-9.

Cook, J. (2019). Understanding and countering misinformation about climate change. In Chiluwa, I. \& Samoilenko, S. (Eds.), Handbook of Research on Deception, Fake News, and Misinformation Online (pp. 281-306). Hershey, PA: IGI-Global.

Dewi, R.P., \& Khoirunisa, N. (2018). Middle school student's perception of climate change at Boyolali District, Indonesia. International Conference on Climate Change IOP Conf. Series: Earth and Environmental Science 200 (2018) 012061 doi :10.1088/17551315/200/1/012061

Dutta, PK., \& Radner, R.A. (2009). Strategic analysis of global warming: Theory and some numbers. J. Econ. Behav. Organ. 2009, 71, 187-209.

FOROYAA Newspaper. (2018). Gambia: 'Current Rate of Deforestation, Land Degradation $\begin{array}{lll}\text { Alarming' } & \text { Environment } & \text { Minister. }\end{array}$ https://allafrica.com/stories/201808150308.html. Accessed 22 ${ }^{\text {nd }}$ May 2021.

Freije, A.M., Hussain, T., \& Salman, E.A. (2017). Global warming awareness among the University of Bahrain science students, Journal of the Association of Arab Universities for Basic and Applied Sciences 22, 9-16. 
Global Climate Action (2019). Climate action path way resilience and adaptation action Table, Global climate action, United Nations Climate Change Marrakech Partnership. https://unfccc.int/sites/default/files/resource/CAP Resilience and Adaptation AT.pdf.

Accessed 27 April, 2021.

Haq, A.M.D.A., \& Ahmed, K.J. (2020). Perceptions about climate change among university students in Bangladesh. Natural Hazards 103:3683-3713. https://doi.org/10.1007/s11069$\underline{020-04151-0}$

Houghton, J.T., Meira-Filho, L.G., Callander, B.A., Harris, N., Kattenberg, A., \& Maskell, K. (1996). Climate change 1995: the science of climate change - contribution of working group I to the second assessment report of the intergovernmental panel on climate change. Cambridge University Press, Cambridge, UK.

Huang, J., Li, Y., Fu, C., Chen, F., Fu, O., Dai, A., Shinoda, M., Ma, Z., Guo, W., Li, Z., Li, L., Zhang, L., Liu, Y., Yu, H., He, Y., Xie, Y., Guan, X., Ji, M., Lin, L., Wang, S., Yan, H., \& Wang, G. (2017). Dryland climate change: Recent progress and challenges, Rev. Geophys., 55, 719-778, doi:10.1002/2016RG000550.

Index Mundi (2019). The Gambia - Forest area (\% of land area). https://www.indexmundi.com/facts/the-gambia/indicator/AG.LND.FRST.ZS. Accessed $22^{\text {nd }}$ May 2021.

IPCC (2013). Intergovernmental Panel on Climate Change (IPCC). Climate change 2007: The physical science basis. Contribution of working group I to the Fourth Assessment Report of the Intergovernmental Panel on Climate Change, ed. S. Solomon, D. Qin, M. Manning, Z. Chen, M. Marquis, K. B. Avery, M. Tignor, and H. L. Miller. Cambridge and New York: Cambridge University Press. https://www.ipcc.ch/report/ar4/wg1/. Accessed 7 May, 2021.

IPCC (2018). Summary for Policymakers. In: Global Warming of $1.5^{\circ} \mathrm{C}$. An IPCC Special Report on the impacts of global warming of $1.5^{\circ} \mathrm{C}$ above pre-industrial levels and related global greenhouse gas emission pathways, in the context of strengthening the global response to the threat of climate change, sustainable development, and efforts to eradicate poverty [Masson-Delmotte, V., P. Zhai, H.-O. Pörtner, D. Roberts, J. Skea, P.R. Shukla, A. Pirani, W. Moufouma-Okia, C. Péan, R. Pidcock, S. Connors, J.B.R. Matthews, Y. Chen, X. Zhou, M.I. Gomis, E. Lonnoy, T. Maycock, M. Tignor, and T. Waterfield (eds.)]. World Meteorological Organization, Geneva, Switzerland, 32 pp. https://www.ipcc.ch/sr15/chapter/spm/. Accessed 1 May, 2021

Kumar, A., Jacob, A., Nimitha, P.N., \& Rakesh, P.S. (2019). A study on KAP regarding environment and global warming in senior secondary school students in Kochi, Kerala. Int J Community Med Public Health. 2019 Jan;6(1):168-172.

Ozbayrak, O., Uyulgan, M., Alpat, S., Alpat, S.K., \& Kartal, M (2011). A research on high school students knowledge related to global warming. Buca Eg`itim Faku“ ltesi Dergisi 29, $58-67$

Parashar, P., Goel, K., Ahmad, S., Bansal, R., \& Sharma, S. (2013). Awareness and Practices Regarding Global Warming and its Health Hazards among the Medical Students of Meerut. 
International Journal of Contemporary Medicine. January-June., 2013, 1 (1). DOI Number: 10.5958/j.2321-1032.1.1.018.

UNEP (2020). Emissions Gap Report 2020, United Nations Environment Programme, 09 December 2020 Report https://www.unep.org/emissions-gap-report-2020.

Van der Linden, S.A., Leiserowitz, S., \& Maibach, R.E. (2017). Inoculating the Public against Misinformation about Climate Change. Global Challenges 2017, 1, 1600008.

Yang, L., Liao, W., Liu, C., Zhang, N., Zhong, S., \& Huang, C. (2018). Associations between Knowledge of the Causes and Perceived Impacts of Climate Change: A Cross-Sectional Survey of Medical, Public Health and Nursing Students in Universities in China. Int. J. Environ. Res. Public Health 2018, 15, 2650; doi: 10.3390/ijerph15122650. 